\title{
Poets and Portuguese Language Poetry: trajectories and projects
}

Raquel Beatriz Junqueira Guimarães*

Raquel S. Madanêlo Souza**

The creative dialogue among Portuguese-speaking poets, as narrated here by Carlos Frederico Manes, a poet from Rio de Janeiro, in an interview with Simone Guerreiro, is a accomplished fact in the history of literature. The transitions among distinct literary projects, diverse national expressions and distinctive languages make it possible for us to take an investigative look at Portuguese Language Literatures, both to establish their proximity and to record their idiosyncrasies. For reasons such as this one, the magazine Scripta of the Graduate Program in Literature of PUC Minas and the Center for Luso-Afro-Brazilian Studies publishes, in this edition, a dossier on the literary productions of poets and contemporary Portuguese language poetry. This issue contains articles, reviews and interviews that present poets and their trajectories, and that carefully analyze literary projects of writers and groups of artists who organize themselves collectively.

The reader will find different reflections on the literatures of Portugal, Brazil, Angola and Mozambique that approach poetry and literary criticism. In the articles, there are several questions related to contemporary poetry and the aesthetic paths taken by the poets: the presence of themes such as the approaches between plastic arts and literature; the presence of literature in digital media and the effects of this contact; the

\footnotetext{
* Pontifical Catholic University of Minas Gerais (PUC Minas). Teacher of the graduate program in Languages.

** Federal University of Minas Gerais (UFMG). Teacher of Portuguese Literature.
} 
problematizations about the relations between canonical works and topics, traditional literary forms and their re-reading in the present time; considerations about gender issues and the presence of the body in the field of literary studies, as well as investigations about memory and colonialism in documentaries and testimonies of artists from Portugal and Africa. From the articles published here it is possible to perceive some trajectories of literary criticism, which both concentrates on theories of poetic studies, proper of the Theory of Literature, and glides to interfaces with Philosophy and Psychoanalysis.

In the set of works present in this dossier, it can be noticed what is considered a trend in the field of literary studies: the interest of critics in female production. There are many works dedicated to literary and artistic projects of different writers.

Although the dossier is organized by Portuguese speaking regions in Europe, Africa and America, we chose in this presentation to highlight thematic approaches among the poets of the different Portuguese speaking countries represented here: Portugal, Mozambique, Angola and Brazil.

In the article by Ida Alves and Beatriz Machado Fonseca, the scenes of writing and reading featured in the poetic and critical productions present in the contemporary magazine Telhados de vidro, directed by the poets Inês Dias and Manuel de Freitas are investigated. Freitas' critical and editorial positioning is also the subject of another work, by Julia Telésforo Osório, which approaches the anthology Poetas sem qualidades and its controversial preface entitled "O tempo dos puetas". Another current Portuguese author, who began his publications in the 1990s, is Daniel Jonas, whose verses are discussed here in two texts: the first, written by Silvana Pessôa, analyzes écfrase as a 
poetic resource that allows to articulate the relationships between literature and the plastic arts. In the second study, by Roberto Bezerra de Menezes, Jonas' poetry is juxtaposed with that of Paulo Henriques Britto, in a comparative analysis that points out the differences between the authors' metapoetic reflections around the sonnet.

The literary projects of Gonçalo Tavares and Herberto Helder are questioned by Ewa A. Łukaszyk, Maria Isabel Bordini and Mariana Pereira Guida. The first two examine some aspects of the resumption of the Camonian epic model by the writer Gonçalo M. Tavares, while Mariana Pereira Guida analyses the myth of Orpheus in the work of Herberto Helder, focusing on aspects of finitude and metamorphosis in the Herbertian project.

Among the works on the condition of women is an article by Tatiana Pequeno, who investigates the issues of gender and sexuality in the production of the writer, daughter of a Portuguese mother and Belgian father, Bénédicte Houart.

The writers' poetics are also approached in several articles of Brazilian Literature. Rafael Quevedo examines the metaphors of navigation in women's lyrics, especially the writers Ana Cristina César (1979), Orides Fontela (1983), Neide Archanjo (1984), Maria Lúcia dal Farra (2011) and Hilda Hilst (1989). This last one has his poetry analyzed in another work, entitled "Casa da Noite: a morada da poesia de Hilda Hilst", in which Vitor Hugo Luís Geraldo and Enivalda Nunes Freitas e Souza analyze the images of the night in a book by the writer. Jailma Garcia analyzes the urban spaces in Marília Garcia's poetry; whereas in the text dealing with the voices of black women, Elaine Correia de Oliveira and Francine Weiss Ricieri approach the saraus and slams in São Paulo; while Fabiana Oliveira de 
Jesus focuses on the representation of the black body of women in the poetry books of writer and artist Maria Tereza. Closing the series of articles about Brazilian writers, Eider Madeiros, Letícia Simões Velloso Schuler and Hermano de França Rodrigues read a poem by Stela do Patrocínio, a writer from Rio de Janeiro, in a proposal of bringing Literature and Psychoanalysis closer together.

In the context of the relations between literature and digital media, Débora Keppi Deicke and Vinícius Pereira's text proposes a discussion about the concept of materiality in the work of cyberpoet Rui Torres. And following the path of reflections on the works of 20th century Portuguese writers, the study by Vinícius Victor Araujo Barros exposes some aspects of the colonial war, based on the testimonial poetry of writers Manuel Alegre and Fernando Assis Pacheco.

Focusing on reflections about arts in Portuguese-speaking countries, we have Aparecida de Fátima Bueno's research on aspects of colonialism and Salazarism, through the analysis of some documentaries by the Angolan Diana Andringa. The article by Luciana Brandão Leal presents the lyrical work of the writer Luís Carlos Patraquim, highlighting, not the aspect already traditionally linked to post-colonial issues in the works of African writers, but focusing on love and eroticism in the writing of the Mozambican poet.

Regarding the Brazilian literary production, in addition to the investigations around the writers' poetics, we can read the article that closes the dossier in which Iouchabel S. de F. Falcão, Célia Maria Domingues da Rocha Reis and Danilo Barcelos analyze a poem by the writer Santiago Vilela Marques from São Paulo, through the heideggerian philosophy. 
The volume is completed with a free section, reviews and interviews. In the free section, the works are not dedicated to the work of poets, but are devoted to the analysis of short stories and novels. Frederico Dias Rosa Alves Teixeira, Flávia Maurício da Rocha Fontes and Priscila Campolina de Sá Campello bring to the scene short stories by Marcela Serrano and Teolinda Gersão, to debate issues related to the body and feminine dimensions. The British literature is present based on the concern of Luiz Fernando Ferreira Sá, who concentrates on novels by Ian McEwan (2001), Jeanette Winterson (1985) and Hilary Mantel (2012) to discuss the interest for the collection in contemporary British fiction.

The three reviews deal with works of Portuguese language literature and highlight poets such as Jacques Fux from Minas Gerais, Juliano Garcia Pessanha from São Paulo and Gonçalo Manuel Tavares from Portugal. In the interviews, Simone Guerreiro talks to the poet Carlos Frederico Manes, with whom she develops an important reflection on literature as a resistance; and Edneia Rodrigues Ribeiro interviews the daughter of João Cabral de Melo Neto, the writer Inez Cabral, who talks about her relationship with her father and her emotion knowing about the existence of a poem dedicated to her.

Good reading to all of you.

The organizers 